\title{
KONSTRUKSI AJARAN ISLAM DALAM NOVEL AYAT-AYAT CINTA DAN BUMI CINTA KARYA HABIBURRAHMAN EL SHIRAZY
}

\author{
Oleh: \\ Haris Supratno \\ Jurusan Bahasa dan Sastra Indonesia, FBS, Unesa \\ (harissupratno@gmail.com).
}

\begin{abstract}
ABSTRAK
Tujuan penelitian ini untuk mengetahui konstruksi ajaran Islam yang terkait dengan iman, Islam, akhlak, dan muamalah dalam novel Ayat-Ayat Cinta dan BumiCinta karya Habiburrahman Ek Shirazy. Metode penelitian ini menggunakan metode kualitatif. Sumber data penelitian ini adalah novel AyatAyat Cinta dan Bumii Cinta karya Habiburrahman Ek Shirazy. Teknik pengumpulan data menggunakan teknik pustaka atau dokumen yang berupa kedua novel tersebut. Teknik analisis data menggunakan teknik analisis deskriptif dan conten analisis.

Hasil penelitian tersebut adalah bahwa dalam novel Ayat-Ayat Cinta dan Bumi Cinta banyak mengkonstruksikan ajaran Islam yang terkait dengan keimanan, keislaman, akhlak dan muamalah. Tokoh utama Fahri dalam novel Ayat-Ayat Cinta dan Ayyas dalam novel Bumi Cinta mampu memeperjuangkan dan mempertahankan keimanannya. Keduanya mampu menjaga imannya melalui salat, puasa, zikir, tasbih, dan menjaga pandangannya terhadap perempuanperempuan cantik yang menggodanya.Kedua tokoh tersebut juga memiliki akhlah yag baik, suka menolong orang lain dengan dilandasi kecintaannya kepada Allah SWT, halus budinya, kuat imannya, teguh mempertahankan prinsip kebenaran, mempunyai visi ke depan, menghormati dan menghargai orang lain, dan tidak mau menyakiti orang lain. Dalam kedua novel tersebut juga mengajarkan kepada manusia agar bekerja keras untuk mencapai kebahagiaan dunia dan beribadat untuk mencapai kebahagiaan akhirat. Kedua kepentingan tersebut harus seimbang, tidak boleh hanya mementingkan kepentingan kebahagiaan dunia atau hanya mementingkan kebahagiaan akhirat. Apa yang dilakukan kedua tokoh tersebut hanya berdasarkan kecintaan kepada Allah SWT dan merupakan suatu kewajiban untuk memenuhi perintah Allah SWT.
\end{abstract}

Kata Kunci : Konstruksi, ajaran Islam, Iman, Islam, Akhlak, dan Muamalah.

\section{A. PENDAHULUAN}

Karya sastra sebagai salah satu unsur kebudayaan, memiliki aneka ragam jenis. Jenis-jenis karya sastra tersebut antara lain berupa karya sastra tulis modern seperti novel, cerpen, drama, dan puisi. Novel merupakan salah satu jenis karya sastra Indonesia yang paling menarik, karena mampu merefleksikan berbagai 
fenomena yang terjadi dalam masyarakat, baik yang terjadi pada masa lampau, masa kini, maupun pada masa yang akan datang. Dalam perkembangan novel sastra Indoneasia, setiap dekade memiliki karakteristik sesuai dengan perkembangan jaman. Novel sastra Indonesia tahun 2000-an juga mempunyai karakteristik yang berbeda dengan novel-novel yang terbit sebelumnya. Novel sastra Indonesia tahun 2000-an banyak merekonstruksikan ajaran Islam, baik yang berhubungan dengan Iman, Islam, Ihsan, akhlak, dan muamalah,baik yang berhubungan dengan masyarakat maupun individu.

Menurut Berger dan Lukman (Manuaba, 2010: 221-225) dalam memahami teori konstruksi sosial Bergerian, ada tiga momen penting yang harus dipahami secara simultan. Ketiga momen itu adalah eksternalisasi, objektivasi, dan internalisasi. Ketigahal tersebut memiliki hubungan dasar dan dipahami sebagai satu proses yang berdialektika satu sama lain. Masing-masing dari ketiga momen itu berkesesuaian dengan suatu karakterisasi yang esensial dari dunia sosial. Melalui eksternalisasi, masyarakat merupakan produk manusia; melalui objektivasi, masyarakat menjadi realitas sui generis, unik; dan melalui internalisasi, manusia merupakan produk masyarakat. Ada proses menarik keluar (eksternalisasi) sehingga seakan-akan hal itu berada di luar (objektivasi), dan lebih lanjut ada proses penarikan kembali ke dalam (internalisasi) sehingga yang berada di luar seakan-akan berada di dalam diri.

Menurut Bergerdan Lukman (Manuaba, 2010 ) produk aktivitas manusia yang berupa produk-produk sosial terlahir dari eksternalisasi manusia. Eksternalisasi adalah suatu pencurahan kedirian manusia terus-menerus ke dalam dunia, baik dalam aktivitas fisis maupun mentalnya. Eksternalisasi merupakan keharusan antropologis; keberadaan manusia tidak mungkin berlangsung dalam suatu lingkungan interioritas yang tertutup dan tanpa-gerak. Keberadaannya harus terus-menerus mencurahkan kediriannya dalam aktivitas. Keharusan antropologis itu berakar dalam kelengkapan biologis manusia yang tidak stabil untuk berhadapan dengan lingkungannya (Berger dan Luckmann,1990:75: Berger,1994:5-6).

Berger (Manuaba,2010), masyarakat adalah produk manusia, berakar pada fenomena eksternalisasi. Produk manusia (termasuk dunianya sendiri), kemudian 
berada di luar dirinya, menghadapkan produk-produk sebagai faktisitas yang ada di luar dirinya. Meskipun semua produk kebudayaan berasal dari (berakar dalam) kesadaran manusia, namun produk bukan serta-merta dapat diserap kembali begitu saja ke dalam kesadaran. Kebudayaan berada di luar subjektivitas manusia, menjadi dunianya sendiri. Dunia yang diproduksi manusia memperoleh sifat realitas objektif (Berger, 1994:11-12). Semua aktivitas manusia yang terjadi dalam eksternalisasi, menurut Berger dan Luckmann (1990:75-76), dapat mengalami proses pembiasaan (habitualisasi) yang kemudian mengalami pelembagaan (institusionalisasi) (Berger dan Luckmann, 1990:75-76).

Internalisasi berlangsung karena adanya upaya untuk identifikasi. Si anak mengoper peranan dan sikap orang-orang yang berpengaruh, dan menginternalisasi serta menjadikannya peranan sikap dirinya. Dengan mengidentifikasi orang-orang yang berpengaruh itulah anak mampu mengidentifikasi dirinya sendiri, untuk memperoleh suatu identitas yang secara subjektif koheren dan masuk akal. Diri merupakan suatu entitas yang direfleksikan, yang memantulkan sikap yang mula-mula diambil dari orang-orang yang berpengaruh terhadap entitas diri itu. Sosialisasi primer menciptakan di dalam kesadaran anak suatu abstraksi yang semakin tinggi dari peranan-peranan dan sikap orang-orang lain tertentu ke peranan-peranan dan sikap-sikap pada umumnya.

Hanafi dan Sobirin (2002:32-33) berpendapat bahwa ajaran Islam menempatkan manusia sebagai makhluk dan sebagai khalifah pada saat bersamaan. Konsep manusia sebagai makhluk merupakan totalitas kepatuhan kepada pencipta-Nya dengan menjalankan seluruh perintah dan menjauhi segala larangan yang telah ditetapkan untuk mencapai kriteria sebagai manusia yang terpilih. Ibadah merupakan pengabdian kepada Tuhan dan merupakan tujuan penciptaan manusia dan makhluk lainnya. Kedudukan manusia sebagai khalifah merupakan atribut yang menuntut manusia yang merdeka, bebas, menguasai seluruh tindakannya dan mempunyai kemampuan obyektif dalam mengaktualisasikan dirinya sebagai bagian dari tugas yang diberikan penciptaNya dalam rangka membangun dan memakmurkan bumi. Dua kedudukan yang 
disandang manusia membawa pada pembagian konsep yang sangat mendasar tentang kajian keilmuan dalam Islam.

Iman, Islam,dan Ihsan merupakan satu kesatuan yang tidak dapat dipisahkan. Iman adalah kepercayaan seseorang yang diucapkan dengan lisan, ditastidkan dalam hati, dan diamalkan dalam perbuatan.Dalam ajaran Islam yang menjadi landasan utama adalah Iman.Rukun Iman ada enam, yaitu iman kepada Allah, iman kepada para Malaikat, iman kepada kitab-kitab Allah, iman kepada para rasul Allah, iman kepada qadar baik maupun buruk (Ma'mur; 2003 : 2).

Menurut Ishak (2002: 63) unsur-unsur iman terdiri dari al-tasdiq bi alqalb; al-iqrar bi al-lisan ; dan al-'amal bi al-jawarih. Ada yang berpendapat unsur ketiga dengan istilah yang lain: al-'amal bi al-arkan yang membawa maksud melaksanakan rukun-rukun Islam. Perbedaan dan persamaan pendapat para mutakallimin dalam konsep iman nampaknya berkisar di sekitar unsur tersebut.Menurut pandangan kaum Khawarij mengatakan pengertian iman itu ialah beriktikad dalam hati dan berikrar dengan lidah serta menjauhkan diri dari segala dosa.

Islam mengandung makna yang sangat luas, namun secara sederhana ajaran Islam dapat dipilah menjadi tiga ranah,yaitu akidah, syari'ah, dan akhlak plus tasawuf (iman, islam, ihsan) (Nasuha, 2009:1).

Menurut Nasuha (2009:2) Islam dapat berarti pasrah, atau menyerah, atau taat. Sedangkan Islam dalam arti konsep adalah agama yang bersifat ketuhanan, yang diturunkan oleh Allah kepada Nabi Muhammad Saw, dalam rangka untuk mensejahterahkan kehidupan manusia di dunia dan di akhirat. Islam terdiri atas ajaran pokok, yaitu akidah dan syari'ah, dan ajaran yang tidak pokok seperti filsafat Islam, kebudayaan Islam, dan model-model ideologi organisasi Islam yang didoktrinkan oleh para pimpinan kepada pengikutnya.

Islam adalah agama yang dibawa Nabi Muhammad saw yang berdasarkan wahyu Allah. Dasar ajaran agama Islam adalah Alqurandan hadis. Rukun Islam ada lima, yaitu mengakui bahwa tidak ada Tuhan selain Allah dan bahwa Muhammad Rasulullah, mendirikan salat, membayar zakat, puasa Ramadhan, dan haji ke Baitullah (Ma'mur; 2003: 42). 
Akhlak merupakan pondasi utama dalam pembentukan karakter pribadi manusia, untuk merealisasikan akhlak dalam kehidupan, perlu adanya pembinaan secara terus menerus (Sylviyanah, 2012:191). Akhlak merupakan warisan maknawi Rasulullah yang amat bernilai karena Rasulullah diutus ke dunia untuk menyempurnakan akhlak manusia.Akhlak merupakan azas untuk memperbaiki perangai, adab, dan kesempurnaan pribadi(Yalawae dan Farid, 2007:71-83).

Bidang kajian akhlak adalah tingkah laku manusia, baik yang bernilai baik (mulia) atau yang bernilai buruk (tercela).Yang dinilai di sini adalah tingkah laku manusia dalam berhubungan dengan Tuhan, yakni dalam melakukan ibadah, dalam berhubungan dengan sesamanya, yakni dalam bermuamalah atau dalam melakukan hubungan sosial antar manusia. Akhlak merupakan konsep kajian terhadap ihsan. Ihsan merupakan ajaran tentang penghayatan akan hadirnya Tuhan dalam hidup, melalui penghayatan diri yang sedang menghadap dan berada di depan Tuhan ketika beribadah. Ihsan juga merupakan suatu pendidikan atau latihan untuk mencapai kesempurnaan Islam dalam arti sepenuhnya (kaffah), sehingga ihsan merupakan puncak tertinggi dari keislaman seseorang. Ihsan ini baru tercapai kalau sudah dilalui dua tahapan sebelumnya, yaitu iman dan islam. Orang yang mencapai predikat ihsan ini disebut muhsin.Dalam kehidupan seharihari ihsan tercermin dalam bentuk akhlak yang mulia (al-akhlak alkarimah).Inilah yang menjadi misi utama diutusnya Nabi Saw.ke dunia, seperti yang ditegaskannya dalam sebuah hadisnya: "Sesungguhnya aku diutus hanyalah untuk menyempurnakan akhlak mulia".

Muamalah adalah kegiatan manusia yang terkait dengan duniawi, baik yang terkait dengan kepentingan diri sendiri maupun yang terkait dengan kepentingan masyarakat yang memberikan manfaat dengan cara yang telah ditentukan, seperti jual beli, tukar menukar barang, sewa-menyewa, upahmengupah, pinjam-meninjam, bercocok tanam, berserikat, tolong-menolong, dan usaha lain (Rasjid, 2010:278). 


\section{B. METODE PENELITIAN}

Penelitian ini menggunakan metode penelitian kualitatif. Metode penelitian kualitatif adalah suatu prosedur penelitian yang menghasilkan data-data deskriptif yang berupa kata tertulis atau lisan dari orang-orang dan perilaku yang dapat diamati (Nasution, 1988: 9-11, Meleong, 1990: 4-7; Supratno, 2010: 66-67).

Objek penelitian ini adalah novel sastra Indonesia tahun 2000-an, yaitu : Ayat-ayat Cinta (2004 dan Bumi Cinta (2010 karya Habiburrahman El Shirazy. Novel-novel tersebut dijadikan objek penelitian ini karena mengandung ajaran Islam yang berhubungan dengan Iman, Islam, Ihsan, akhlak, dan muamalah.

Metode pengumpulan data penelitian ini menggunakan metode pustaka atau dokumen. Teknik analisis data penelitian ini menggunakan teknik analisis deskriptif dan content analisys(Baylai, 1987: 300 ; Supratno, 2010: 76).

\section{PEMBAHASAN}

Di atas telah dijelaskan bahwa teori yang digunakan dalam penelitian ini adalah teori Konstruksi Berger. Menurut Berger dan Lukman (Manuaba, 2010: 221-225) dalam memahami teori konstruksi sosial Bergerian, ada tiga momen penting yang harus dipahami secara simultan. Ketiga momen itu adalah eksternalisasi, objektivasi, dan internalisasi. Ketigahal tersebut memiliki hubungan dasar dan dipahami sebagai satu proses yang berdialektika satu sama lain. Masing-masing dari ketiga momen itu berkesesuaian dengan suatu karakterisasi yang esensial dari dunia sosial. Melalui eksternalisasi, masyarakat merupakan produk manusia; melalui objektivasi, masyarakat menjadi realitas sui generis, unik; dan melalui internalisasi, manusia merupakan produk masyarakat.

Secara eksternalisasi, masyarakat merupakan produk manusia, maka bila manusia yang tinggal dalam masyarakat tertentu baik, maka akan menghasilkan masyarakat yang baik. Sebaliknya, bila manusia yang tinggal dalam suatu masyarakat pada umumnya tidak baik, maka akan menghasilkan masyarakat yang tidak baik.

Dalam novel Ayat-Ayat Cinta digambarkan keluarga Fahri yang sangat sederhana. Orang tuanya hanya memiliki sebuah rumah peninggalan kakeknya yang sangat sederhana dan sawah seperempat bahu. Ayahnya tetap menggarap sawahnya dengan ditanami padi yang hanya bisa dimakan sendiri. Untuk 
menutupi kebutuhan lain, Ibunya menjual gorengan di pasar dan ayahnya jualan tape dengan berkeliling dari kampung ke kampung. Di hari Minggu Fahri juga diajak berjualan tape ayahnya. Bila sudah sampai di kampung ayahnya berteriak menawarkan dagangannya, 'Pe tape! Pe tape! Pe tape!'Bila ayahnya lelah, Fahri yang mengantikan ayahnya berteriak menawarkan tape (Shirazy, 20005: 148).

Secara struktur sosial, keluarga Fahri merupakan keluarga kelas menengah bawah yang hidup sederhana dan damai. Antara kedua orang tuanya saling menyadari atas keberadaannya, sehingga saling bekerja untuk menutupi kebutuhan hidupnya. Keluarga yang sederhana dan damai tersebut merupakan produk dari anggota keluarga atau manusia yang baik, yang saling memahami keberadaannya, saling toleransi, dan saling mencintai. Hubungan kedua orang tua dan anaknya baik, sehingga membentuk keluarga yang sederhana dandamai.

Dalam novel Bumi Cinta digambarkan masyarakat pesantren Kajoran Magelang tempat tokoh Muhammad Ayyas mencari ilmu, khususnya ilmu agama. Pesantren bukan hanya sekedar menimba ilmu, tetapi juga tempat mengembleng keimanan tokoh Muhammad Ayyas, sehingga Ayyas menjadi tokoh santri salaf yang memiliki iman yang kuat.

Ayyas kemudian meneruskan kuliah ke S2, mengambil Magister di Universitas di Madinah. Kehidupan masyarakat di Madinah tidah begitu jauh dengan kehidupan masyarakat Indonesia, artinya masyarakatnya masih menjunjung tinggi etika dan norma agama, sehingga iman Ayyas semakin kuat. Masyarakat Madinah adalah masyarakat yang baik dan religius, karena Madinah adalah tempat hidup Rasulullah SAW sampai akhir hayatnya. Kebaikan dan religiusnya masyarakat Madinah merupakan produk manusia yang tinggal di Madinah yang sebagian besar Muslim. Kehidupan masyarakat Madinah yang religius tersebut yang ikut andil dalam membentuk karakter tokoh Muhammad Ayyas yang memiliki iman yang kuat, yang berjuang mati-matian untuk mempertahankan dan memperjuangkan keimanannya di tengah-tengah masyarakat Rusia yang sangat bebas pergaulan dan free sex-nya.

Kekuatan iman Ayyas mungkin masih kuat karena hidup di Indoesia dan di Madinah. Namun, kekuatan iman Ayyas sebagai santri salaf belum tentu mampu untuk mempertahankan imannya bila hidup di negeri Rusia, negeri yang 
sangat bebas di dunia dalam pergaulan dan free sex radikal dan negara pengakses situs porno terbesar di dunia.

Dalam novel BumiCinta juga digambarkan kehidupan masyarakat Rusia yang sangat bebas dalam pergaulan dan free sex-nya. Kota Moskwa yang sangat terkenal dengan kehidupan bagaikan surga kebebasan di dunia. Kehidupan masyarakat yang sebagian besar tidak mengenal agama. Mereka beranggapan bahwa hidup yang bahagia adalah hidup yang bebas tidak terikat oleh aturan-atran agama. Masyarakat Rusia yang kehidupan pada umumnya sangat bebas dalam pergaulan dan free sex-nya dan tidak terikat pada aturan agama, merupakan poduk manusia Rusia yang pada umumnya sejak dulu menganut ajaran Marxisme, yang tidak mengakui adanya Tuhan. Di Rusia inilah tokoh santri salaf, Ayyas berjuang dan mempertahankan keimanannya. Keimanannya diuji dengan kecantikan wanita, seperti Yalena, Linor, dan Anastasia, yang dapat meruntuhkan iman seorang laki-laki normal mana pun. Kecantikan wanita merupakan salah satu godaan iman yang paling berat. Hal tersebut sesuai dengan kutipan sebagai berikut: "Di negara seperti Rusia, orang-orang yang beriman tidaklah mudah menjaga dan mempertahankan imannya. Musuh iman di mana-mana. Berkeliaran setiap detik. Dan mereka lebih kejam, lebih buas, lebih licik, dan lebih sadis bila dibandingkan dengan musuh-musuh iman yang ada di negara yang terkenal bebas dan sekuler seperti Amirika Serikat sekalipun" (Shirazy, 2010: 6).

Secara objektivasi, realitas sosial atau fenomena sosial yang terjadi dalam masyarakat merupakan hasil dari produk masyarakat. Masyarakat yang baik akan memproduk atau menghasilkan manusia atau anggota masyarakat yang baik, sehingga di dalam masyarakat akan terjadi realitas atau fenomena sosial yang cenderung melakukan hal-hal yang baik, sesuai dengan budaya yang dianut oleh sebagian besar masyarakat. Realitas sosial atau fenomena sosial yang akan dibicarakan ini mencakup realitas yang berhubungan dengan Iman, Islam, akhlak dan muamalah. Keempat tersebut akan dijelaskan sebagai berikut:

\section{Konstruksi Ajaran Islam yang berhubungan dengan Iman}

Konstruksi ajaran Islam dalam novel Ayat-Ayat Cinta yang berhubungan dengan iman direfleksikan melalui tokoh utamanya lain Fahri. Tokoh Fahri merupakan produk masyarakat yang baik, sehingga segala sikap,perilaku, dan 
tutur bahasa Fahri cenderung untuk melakukan hal-hal yang baik dalam kehidupan sehari-hari dalam masyarakat. Fahri adalah seorang mahasiswa yang pandai, hafal Alquran, berbudi baik, suka menolong orang lain, dan sangat tekun beribadah serta menjalankan ajaran Islam dalam kehidupan sehari-hari di tengahtengah kehidupan kota Mesir.

Fahri digambarkan sebagai seorang mahasiswa yang mempunyai iman yang kuat, memiliki semangat belajar yang tinggi, sehingga di tengah-tengah cuaca panas di kota Mesir, ia tetap keluar dari asramanya untuk belajar Alquran secara langsung kepada ulama besar Mesir yang bernama Syaikh Mahmoud Khushari. Ia merupakan satu-satunya murid dari Indonesia dan menjadi anak emas sang guru dari sepuluh muridnya. Kekuatan iman Fahri itulah yang telah menggerakkan hatinya tetap keluar dari asrama untuk belajar Alquran kepada Syaikh Mahmoud Khushari. Hanya orang-orang yang benar-benar tebal imannyalah yang mau dan mampu menggugah dan menggerakkan hati mereka untuk pergi salat berjamaah ke masjid. Hal tersebut tampak dalam kutipan sebagai berikut: "Memang, istirahat di dalam flat sambil menghidupkan pendingin ruangan jauh lebih nyaman daripada berjalan ke luar rumah, meski sekedar untuk shalat berjamaah di masjid. Panggilan azan Zuhur dari ribuan menara yang bertebaran di seantero kota hanya mampu menggugah dan menggerakkan hati mereka yang benar-benar tebal imannya" (Shirazy, 2005; 26).

Fahri juga digambarkan sebagai seorang yang mempunyai iman yang kuat dan mempunyai semangat yang tinggi belajar ilmu agama, sehingga ia menjadi salah satu mahasiswa yang terpandai dan hafal Alquran di antara mahasiswa yang lain serta menjadi anak emas Syaikh Mahmoud Khushari. Hal tersebut tampak dalam kutipan sebagai berikut:

Tahun ini, setelah melalui ujian ketat beliau hanya menerima sepuluh orang murd. Aku termasuk sepuluh orang yang beruntung itu. Lebih beruntung lagi, beliau sangat mengenalku. Itu karena sejak tahun pertama kuliah aku sudah menyetorkan hafalan Alquran pada beliau di serambi Masjid Al-Azhar. Juga karena di antara sepuluh orang yang terpilih itu ternyata hanya diriku seorangyang bukan orang Mesir. Aku satu-satunya orang asing dan sekaligus satu-satunya yang dari Indonesia. Tak heran jika beliau menganakemaskan diriku. Dan teman-teman dari Mesir tidak ada yang merasa iri dalam masalah ini, mereka semua simpati padaku (Shirazy, 2005: 17). 
Dalam novel Ayat-Ayat Cinta digambarkan realitas sosial atau fenomena sosial yang terjadi dalam masyarakat Mesir. Mayoritas masyarakat Mesir mempunyai keimanan kepada kitab suci Alquran. Keimanan seseorang atau masyarakat Mesir kepada kitab suci Alquran, bukan hanya diucapkan dalam lisan, ditasditkan dalam hati, tetapi sudah diamalkan dalam perbuatan sehari-hari oleh masyarakat Mesir. Orang -orang Mesir sudah terbiasa dan bukan merupakan pemandangan yang aneh bila di kerata, di bus, di stasiun, di terminal banyak orang yang membaca Alquran. Apalagi pada bulan puasa, di mana-mana orangorang Mesir selalu membaca Alquran, seakan-akan suara Alquran mendengung di seluruh kota Mesir/Kairo. Hal tersebut sama dengan pemandangan di Eropa, Amirika, dan Jepang, di kereta, di stasiun, di bus kota, apalagi di kampus, orangorang banyak membaca buku. Hal tersebut juga sudah menjadi pemandangan dan budaya yang tidah aneh lagi. Budaya membaca Alquran tersebut tampak pada kutipan sebagai berikut: "Orang-orang membaca Alquran di metro, di bis, di stasiun, dan di terminal adalah pemandangan yang tidah aneh di Cairo. Apalagi di bulan puasa tiba. Alquran seakan berdengung di seluruh penjuru kota Cairo" (Skirazy, 2005: 36).

Keimanan Fahri terhadap Alquran juga bukan sekedar percaya dan menganggap suci kepada Alquran. Mekipun ia telah hafal Alquran, tetapi ia tetap selalu emangat belajar membaca dan menghafal dengan benar serta mengkaji kandungan atau isi Alquran serta mengamalkan ajaran-ajarannya dalam kehidupan sehari-hari dalam masyarakat. Di tengah-tengah kesibukannya yang padat, ia selalu menyempatkan mengaji dan belajar Alquran. Untuk mengaji Alquran, ia tidak takut berbagai tantangan seperti teriknya matahari dan jauhnya tempat belajar. Setiap Minggu dua kali, ia harus belajar Alquran kepada Syaikh Usman Abdul Fattah yang jauhnya sekitar lima puluh kilometer dari tempat tinggalnya di apartemen. Semangat Fahri belajar Alquran tersebut tampak pada kutipan berikut:

"Siang yang melelahkan. Umbun-umbun kepalaku rsanya mendidih. Cuaca benar-benar panas. Yng berangkat talaqqi (belajar menghafal Alquran berhadapan langsung dengan gurunya) pada Syaikh Utsman hanya tiga orang. Aku, Mahmoud dan Hisyam. Syaikh Utsman jangan ditanya. Disiplin beliau luar biasa ... Aku bertiga membaca tigs ksli lipst dsri bissanya. Jatah membaca Alquran sepuluh orang kami bagi bertiga ((Skirazy, 2005: 57)"'. 
Fahri selalu berusaha untuk menjaga imannya dengan selalu ingat kepada ajaran Islam, menjalankan perintah ajaran Islam dan berusaha belajar menjauhi larangannya. Pada saat Fahri menolong perempuan bercadar putih di sebuah tren, yang telah dicaci maki oleh orang Mesir, perempuan tersebut mengucapkan terima kasih dan mengenalkan dirinya dengan menyebutkan namanya sambil mengulurkan tangannya untuk berjabar tangan dengan Fahri. Namun, Fahri dengan rasa hormat menangkupkan kedua tangannya kedadanya sebagai penolakan secara halus uluran tangan perempuan bercadar tersebut. Penolakan secara halus tersebut bukan berarti merupakan bentuk penghinaan kepada perempuan bercadar tersebut, tetapi merupakan refleksi dari kuatnya iman Fahri, karena ajaran Islam tidak membolehkan seorang laki-laki bersalaman dan bersentuhan dengan perempuan yang bukan muhrimnya. Fahri mencoba menjelaskan kepada perempuan tersebut, alasannya tidak mau bersalaman dengan perempuan tersebut, agar tidak terjadi salah paham dan tidak dianggap menghinanya. Hal tersebut tampak dalam kutipan sebagai berikut: “... My name is Fahri, jawabku sambil menangkupkan kedua tanganku di depan dada, aku tidak mungkin menjabat tangannya."Ini bukan berabti saya tidak menhormati Anda. Dalam ajaran Islam, seorang lelaki tidak boleh bersalaman dan bersentuhan dengan perempuan selain istri dan mahramnya". Aku menjelaskan agar dia tidak salah paham.” (Shirazy, 200554-55).

Kekuatan iman Fahri dalam kehidupan di dalam masyarakat, juga tampak pada saat Fahri diajak makan oleh keluarga Maria. Fahri sebenarnya sudah diskenario oleh ayah Maria, yaitu Tuan Boutros agar duduk berdua dengan Maria di jok mobil belakang yang ditumpangi oleh kedua orang tuanya. Namun, Fahri dengan rasa penuh hormat menolaknya, dan minta diperbolehkan duduk di jok depan karena agar dapat berbincang-bincang dengan ayah Maria. Permintaan Fahri tersebut dikabulkan oleh ibu Maria yang bernama Madame Nahed. Akhirnya Maria duduk di jok belakang bersama ibunya dan Fahri duduk di jok depn di samping ayang Maria. Fahri dengan rasa hormat tetap mau mengikuti permintaan orang tua Maria dalam satu mobil. Namun, ia tidak mau duduk di jok belakang bersama Maria. Ia takut lemah imannya duduk berdua bersanding 
dengan perempuan yang sangat cantik. Gambaran kekuatan iman Fahri tersebut tampak dalam kutipan sebagai berikut:

Tuan Boutros mengatur siapa yang ikut mobilnya dan siapa yang ikut mobil Yousef.... Aku melangkah ke mobil Yousef. Namun, Tuan Boutros memanggil, "Fahri, kau ikut aku!"

"Ya, kau naik sini Fahri!" seru Madame Nahed...

Madame Nahed naik di depan duduk di samping Tuan Boutros. Maria di belakang. Masak aku harus duduk di samping Maria. Dan parfumnya itu. Nuraniku tidak setuju. Satu mobil tak apa, tapi selama tempat duduk bisa diatur lebih aman di hati kenapa tidak. Aku mendekati Madame Nahed dan berbicara dengan halus.

"Maaf Madame, boleh saya duduk di depan. Saya ingin berbincangbincang dengan Tuan Boutros selama dalam perjalanan".

Madame Nhed terseyum, "Oh ya, dengan senanghati".

Dia lalu turun dan pindah ke belakang duduk di samping putrinya. Aku naik dan duduk di samping Tuan Boutros (Shirazy, 2005: 124).

Fahri tidak mau mengunakan kesempatan untuk bisa duduk bersanding dengan Maria, seorang wanita yang sangat cantik dan baunya sangat harum, karena perbuatan tersebut bisa melemahkan imannya. Dalam Alquran sesorang dilarang mendekati zina, latakrabus zina. Fahri tetap berusaha selalu mempertahankan imannya agar tidak melanggar ajaran Islam.

Pada waktu makan malam di lestoran, Fahri juga mendapat ujian iman lagi. Orang tua Maria menyuruh Maria agar mengajak Fahri untuk berdansa. Maria segera mendekati Fahri dan mengajak dansa. Dengan secara halus Fahri mencoba menolaknya, dengan menangkupkan dua tanggannya di depad dadanya, sambil minta maaf, ia tidak bisa menari.

Maria berusaha membujuk Fahri lagi, Maria juga mengaku tidak bisa menari, ia mengajak belajar bersama-sama. Fahri dengan secara halus, sekali lagi minta maaf kepada Maria, sambil berkata bahwa ajaran Alquran dan Sunah melarang seorang lelaki bersentuhan dengan wanita yang bukan muhrimnya. Ujian dan kekuatan iman Fahri tersebut tergambar dalam kutipan sebagai berikut:

"Fahri, maucoba berdansa denganku? Ini kali pertama aku mencoba berdansa ", lirihnya malu. Aku harus berbuat apa. Apakah aku harus ikut budaya Eropa...Tawaran Maria bagi seorang pemuda adalah tawaran menarik. Siapa tidak suka bergandeng tangan dan berdansa dengan gadis secantik dia. Di sinilah letak ujiannya.

"Maaf aku tidak bisa," jawabku sambil terseyum dan menangkapkan dua tangan di depan dada. 
"Sama, aku juga tidak bisa" Kita belajar bersama-sama pelan-pelan. Ayo kita coba!"

"Maafkan aku Maria. Maksudku aku tidak mungkin bisa melakukannya. Ajaran Alquran dan Sunah melarang aku bersentuhan dengan perempuan kecuali dia istri dan mahramku"

Kuaharap kau mengerti dan tidak kecewa!" terangku tegas. Dalam masalah seperti ini aku tidak boleh membuka ruang keraguan yang membuat setan masuk ke dalam aliran darah (Shirazy, 2005: 132-133).

Kutipan tersebut membuktikan bahwa Fahri selalu berusaha untuk menjaga kesucian imannya. Ia tidak mau memanfaatkan kesempatan sekecil apa pun untuk memberikan kesempatan kepada nafsunya untuk mengikuti langkah setan. Ia tetap selalu berusaha untuk mengamalkan ajaran Islam dalam pergaulan sehari-harai dalam masyarakat. Ia tidak mau melanggar ajaran Islam.

Dalam novel Bumi Cinta juga digambarkan tokoh Muhammad Ayyas, seorang santri salaf yang sedang mengadakan penelitian di Rusia untuk penulisan tesisnya, yaitu mengambil sejarah orang Islam di Rusia jaman pemerintahan Lenin dan Stalin. Tokoh Ayyas sebagai seorang sanri salaf yang digambarkan mempunyai karakter dan iman yang kuat yang setiap harinya mendapatkan ujian berhadapan dengan perempuan-perempuan Rusia yang sangat cantik, yang dapat meruntuhkan iman bagi laki-laki normal siapa pun, yang lemah imannya.

Ayyas merupakan contoh pemuda santri salaf yang kuat mempertahankan dan memperjuangkan imannya dan setiap ia berhadapan dan mendapat ujian dengan bertemu dengan perempuan cantik, seperti Yalena, Linor, dan Anantasia, ia selalu berusaha menjaga imannya, dengan menjaga pandangganya dan selalu ingat kepada Allah SWT. Untuk menjaga imannya pada saat ia mendapatkan ujian iman, ia selalu berdoa kepada Allah SWT agar diselamatkan imannya. Hanya Allah SWT yang dapat menyelamtkan imannya. Oleh sebab itu, ia selalu berdoa, beristifar, dan salat setiap mendapatkan ujian imannya. Gambaran Ayyas dalam menghadapi ujian imannya tampak dalam kutipan berikut: "Ayyas merasa dirinya akan sangat lemah, imannya pasti akan runtuh di Moskwa jika tidak ditolong dan dijaga oleh Allah Taala. Ia tahu seberapa kuat imannya. Perang melawan musuh di medan perang mungkin ia akan tetap tangguh sampai tubuh gugur bertumpah darah....Tapi di hadapan fitnah kecantikan perempuan sejelita gadis-gadis Moskwa seperti Yalena, gadis pembawa biola dan gadis yang bersamanya di 
pesawat, ia merasa imannya perlahan bisa lumer bagai garam disiram air. Ia merasa tidak punya benteng dan senjata apapun untuk menjaga imannya, kecuali berdoa kepada Allah agar iman yang ada dalam hatinya tidak tercabut dalam kondisi apaun. Hal tersebut sesua dengan Firman Allah SWT dalam Surat AlBaqarah yang artinya: Mohonla pertolongan Allah dengan sabar dan salat. Dan salat itu sungguh berat, kecuali bagi orang-orang yang khusuk "(Shirazy, 2010: 40).

Ujian iman Ayyas pertama-tama telah diuji, ia tinggal satu apartemen dengan perempuan-perempuan cantik seperti Yalena dan Linor, gadis Rusia yang sangat cantik, bahkan kamarnya bersebelahan dengan kamar Yalena dan Linor. Pada suatu malam, kamar Ayyas diketuk oleh seseorang. Ayyas segera membuka pintunya, alangkah terkejutnya ternyata yang mengetuk pintu adalah Yalena. Hati Ayyas berdesir melihat kecantikan Yalena. Kecantikan Yalena benar-benar nyaris telah membuat iman Ayyas hampir runtuh. Ayyas merasa gugup menghadapi Yalena. Ia mengajak makan malam berdua. Ayyas merasa imannya telah diuji lagi. Ayyas dengan terpaksa makan bersama Yalena dengan saling berhadapan. Ayyas banyak menunduk, perang melawan dirinya sendiri, berusaha sekuat tenaga untuk menjaga pandangannya, karena setan bisa menjerumuskannya. Dalam ajaran Islam seorang laki-laki tidak boleh berduaan dengan wanita yang bukan muhrimnya. Gambaran ujian dan berjuang mempertahankan iman Ayyas tersebut tampak pada kutipan berikut: "Ayyas terpaksa keluar kamar dan makan bersama Yalena di ruang tamu. Yalena mengambil tempat tepat berhadapan dengan Ayyas. Pemuda yang pernah kuliah di Madinah itu banyak menunduk, ia berperang melawan dirinya sendiri, berusaha sekuat enaga untuk menjaga pandangannya" (Shirazy, 2010: 50).

Di tengah tengah makan bersama mereka saling berdiskusi tentang kepercayaan atau agama yang dipeluknya. Yalena mengatakan, ia tidak beragama apa pun dan tidak percaya kepada agama dan Tuhan. Ayyas sebagai seorang santri salaf berusaha untuk memperjuangkan keimanannya, bahwa Tuhan it tetap ada. Walaupun orang-orang mengatakan Tuhan tidak ada, tetapi Tuhan tetap ada. Tuhan sudah ada sebelum alam semesta ini ada, termasuk dunia seisinya. Keberadaan Tuhan merupakan kebenaran postulat, yaitu kebenarannya yang 
paling tinggi dalam tingkatan kebenaran. Kebenaran yang tidak bisa terbantahkan (Shirazy, 2010: 52).

Keimanan Ayyas sering mendapat ujian dari Yalena. Ia tidak bisa menolah setiap diajak berbincang-bincang setiap pagi sebelum Yalena pergi dan di waktu malam setelah Yalena pulang kerja. Yalena selalu berpakaian yang menguji keimanan laki-laki mana pun yang sehat akal dan jasmaninya. Pada saat Ayyas pulang dan masuk ke ruang tamu, Ayyas melihat Yalena berada di ruang tamu dengan berpakaian yang tidak genap menutup aurat, yang dapat meruntuhkan iman seorang laki-laki. Yalena mengajak Ayyas untuk menghangatkan tubuhnya sambil berbincang-bincang. Ayyas minta maaf tidak bisa menuruti ajakan Yalena dengan tetap berusaha menahan tidak memandang Yalena, takut kalau imannya tergoncang. Perjuangan Ayyas untuk menjaga imannya tersebut tampak dalam kutipan sebagai berikut: "Maaf Yalena, aku tidak bisa. Sebaiknya aku istirahat saja”. Kata Ayyas dengan tetap menahan untuk tidak memandang ke arah Yalena... karena takut imannya goyang (Shirazy, 2010: 91).

Kekuatan iman Ayyas juga diuji oleh Linor. Pada suatu malam saat Ayyas sedang salat, Linor masuk kamar Ayyas dan duduk di kursi di belakang Ayyas sedang salat. Linor telah mengenakan gaun jersey putih halus berpayet yang pernah dipakai di waktu lalu gagal diperlihatkan kepada Ayyas. Dengan menggunakan gaun itu, ia yakin akan mampu meluluhkan iman lelaki mana pun. Linor yakin Ayyas belum pernah menyentuh wanita, ia ingin dirinyalah yang disentuh Ayyas pertama kali. Setelah salat selesai, ia melihat Linor sudah duduk di kursi belakang ia salat. Ayyas menegur Linor telah masuk kamarnya tanpa izin. Ia minta agar Linor segera keluar. Tetapi, linor justru agar Ayyas membantu Linor di kamarnya. Ayyas tahu maksudnya Linor. Ayyas sadar bahwa bila ia akan melakukan sesuatu seeperti ajakan Linor, tidak ada orang yang tahu. Linor semakin agresip bergerak mendekati Ayyas. Ayyas hampir akal sehatnya tertutupi oleh apa yang dilihatnya. Ayyas hampir tergelincir ke dalam dosa besar, salatnya hampir sia-sia belaka. Tetapi, Ayyas segera sadar meskipun tidak ada orang yang tahu bila ia melakukan dosa, tetapi Tuhan pasti melihatnya.

Linor menganggap Ayyas mau menuruti ajakannya. Ayyas minta Linor mendekat dan segera membalikan tubuhnya. Linor mengikuti perintah Ayyas, maka begitu 
Ayyas melihat punggung Linor ia segera mengetuk satu titik di punggung Linor dengan pukulan yang cukup keras. Linor menjerit keras lalu pingsan. Ayyas segera menagkap tubuh Linor agar tubuhnya tidak jatuh ke lantai. Ayyas selamat dari perbuatan dosa (Sharizy, 2010: 370).

Linor akhirnya juga sadar dan sangat kagum kepada Ayyas. Ia tidak menodai dirinya ketika dalam keadaan pingsan. Kecantikan dirinya yang selama ini sangat dibanggakan, ternyata sama sekali tidak menarik hati Ayyas. Penampilannya yang ia anggap bisa meruntuhkan imannya, ternyata tidak menggoyahkan iman Ayyas sedikit pun. Ia nyaris tidak percaya kalau ada seorang pemuda yang sangat tangguh imannya dan mampu menjaga kesuciannya.

Iman Ayyas juga diuji lagi pada saat bertemu dengan Prof Abraham Tomskii di Universitas Negeri Moskwa atau Moskvskyj Gosudarstvennyj Universiteitimeni Lomonosova (MGU). Ia bertemu dengan seorang perempuan muda yang sangat cantik, cerdas, dan memesona. Ketiga karuniaTuhan yang sangat jarang dimiliki oleh kaum wanita, yang bernama Dr. Anantasia. Bahkan ia akan menjadi pembimbinganya ketika Ayyas sedang mengadakan penelitian di Moskwa. Pada saat bertemu pertama kali dengan Dr. Anastasia, kedua matanya bertemu pandang dengan Anastasia, hatinya merasa berdesir lebih hebat pada saat bertemu dengan Yalena. Wajahnya merah, dan ia segera menundukkan muka sambil berdoa kepada Allah SWT, “Ya Allah jauhkan hamba-Mu dari kejahatan dan fitnah yang ditimbulkan oleh wajah jelita nonik-nonik muda Rusia ...." (Shirazy, 2010: 81).

Iman Ayyas juga diuji lagi oleh Anastasia. Anastasia jatuh cinta kepada Ayyas. Jatuh cinta kepada pemuda Indonesia yang bahasanya begitu santun, rendah hati dan sangat menghormati dirinya. Anastasia bukan hanya tertarik kepada Ayyas, tetapi sudah jatuh cinta. Hal tersebut tampak pada kutipan berikut: "Bahasanya begitu santun, rendah hati dan sangat menghormati dirinya. Itu yang mungkin membuat hatinya tertarik. Ah, bukan tertarik, tapi jatuh cinta rasanya...Pemuda Indonesia itu benar-benar telah memenuhi lebih dari separo hatinya" (Shirazy, 2010: 138).

Untuk selalu menjaga keimanannya selama hidup di Moskwa, Ayyas selalu salat, membaca Alquran, wiridan, dan berzikir. Ia tidak mau meninggalkan 
kebiasan salat, membaca Alquran, wiridan, dan berzikir kepada Allah SWT, karena itulah yang bisa menjaga imannya. Hal tersebut tampak dalam kutipan sebagai berikut: “ ia merasa salat, membaca Alquran, zikir, dan membaca buku adalah nutrisi jiwanya yang harus ia jaga betul-betul. Ia tidak mau sedikit pun meninggalkan kebiasaan wiridan dan zikir kepada Allah ....” (Shirazy, 2010: 58).

\section{Konstruksi ajaran Islam yang berhubungan dengan Islam}

Dalam pendahuluan telah dijelaskan bahwa Islam mengandung makna yang sangat luas, namun secara sederhana ajaran Islam dapat dipilah menjadi tiga ranah,yaitu akidah, syari'ah, dan akhlak plus tasawuf (iman, islam, ihsan) (Nasuha, 2009:1).

Islam adalah agama yang dibawa Nabi Muhammad saw yang berdasarkan wahyu Allah. Dasar ajaran agama Islam adalah Alqurandan hadis. Rukun Islam ada lima, yaitu mengakui bahwa tidak ada Tuhan selain Allah dan bahwa Muhammad Rasulullah, mendirikan salat, membayar zakat, puasa Ramadhan, dan haji ke Baitullah (Ma'mur; 2003: 42).

Dalam novel Ayat-Ayat Cintabanyak digambarkan ajaran Islam, bukan semata-mata ajarannya yang masih dalam tataran konsep yang ada dalam Alquran dan Sunah Rasul, tetapi ajaran Islam yang sudah diterapkan dalam kehidupan di masyarakat melalui sikap, perilaku, dan tutur bahasa yang halus dan sopan melalui tokoh-tokoh utamanya. Ajaran Islam tersebut antara lain, belajar Alquran, salat, puasa, umrah, dan berbuat baik kepada orang lain.

Secara objektivasi, masyarakat akan mengahsilkan realitas sosial atau fenomena sosial yang ada dalam masyarakat. Masyarakat yang baik akan menghasilkan realitas sosial yang cenderung baik, yaitu masyarakat yang religius. Dalam novel Ayat-Ayat Cinta ,digambarkan tokoh Fahri merupakan salah tokoh utama yang selalu konsisten memperjuangkan, membela, dan mengamalkan ajaran Islam di tengah-tengah kesibukan sehari-hari dalam masyarakat. Sebagai seorang Islam yang taat, ia sangat mencintai, menghormati, mengamalkan ajaran Alquran. Meskipun ia sudah hafal Alquran, tetapi ia tetap selalu belajar talaqqi, yaitu belajar hafalan Alquran berhadapan langsung dengan Syaikh Utsman Abdul Fattah. Fahri memiliki semangat belajar Alquran yang tinggi, tidak takut suasana panas dan tempat yang jauh. Semangat belajar Fahri terhadap Alquran tersebut 
tampak pada kutipan sebagai berikut: "Dengan tekad bulat, setelah mengusir segala rasa aras-arasen aku bersiap untuk keluar. Tepat pukul dua belas siang aku harus sudah berada di Masjid Abu Bakar Ash-Shidiq yang terletak di Shubra ElKhaima, ujung utara Cairo, untuk belajar talaqqi kepada Syaikh Utsman Abdul Fattah" (Shirazy, 2005: 16).

Kutipan tersebut menggambarkan bahwa Fahri meskipun sudah hafal Alquran, tetapi masih mempunyai semangat yang tinggi untuk selalu belajar Alquran. Dalam belajar Alquran, ia tidak takut panas dan teriknya matahari dan tidak takut karena tempatnya yang sangat jauh. Suasana panas dan tempat jauh bukan merupakan penghalang bagi Fhri untuk belajar Alquran.

Di tengah-tengah kesibukan Fahri, ia tidak pernah lupa selalu menjalan ajaran Islam, yaitu salat, karena salat menurut ajaran Islam harus selalu dilaksanakan lima kali sehari semalam, tidak boleh ditinggalkan, walau dalam keadaan apa pun, selama tidak gila, tidur, atau berhalangan bagi wanita. Suasana panas di luar flat, bukan merupakan penghalang bagi Fahri untuk salat berjamaah ke masjid. Fahri selalu berusaha salat berjamaah di masjid, karena salat berjamaah di masjid pahalanya tujuh puluh kali lipat daripada salat sendirian di rumah. Gambaran tesebut tampak pada kutipan sebagai berikut: "Aku cepat-cepat melankah ke jalan menuju masjid untuk salat Zuhur. Panasnya bukan main ...." (Shirazy, 2005: 22).

Di Mesir merupakan negara Islam yang masyarakatnya mayorita beragama Islam, sehingga terdapat beratus-ratus bahkan beribu-ribu masjid, sehingga setiap menjelang manjing waktu salat, maka kumandang adan saling menggema dan bersaut-sautan di seluruh angkasa kota Mesir sampai ke pelosok desa. Pada saat panggilan adan dan iqamat terdengar saling bersautan, Fahri segera bergegas menuju masjid untuk salat berjamaah. Bila terdengar panggilan adan sangat menentramkan hati, pintu-pintu untuk meraih paha,kebahagiaan, dan kesejahteraan terbuka lebar bagi hamba-hamba Allah SWT yang mendapatkan hidayah, karena menjalankan salat pada dasarnya adalah berat bagi orang-orang yang belum atau tidak mendapatkan hidayah dari Allah SWT. Gambaran Fahri ranjin salat berjamaan ke masjid tersebut tampak dalam kutipan berikut:

"Panggilan iqamat"terdengar bersahut-sahutan. Panggilan mulia itu tedengar sangat menentramkan hati. Pintu-pintu meraih kebahagiaan dan 
kesejahteraan masih terbuka lebar-lebar. Kupercepat langkah. Tiga puluh meter di depan adalah Masjid Al-Fath-Islami. Masjid kesayangan. Masjid penuh kenangan tak terlupakan ....Tempat aku mengadu pada Yang Maha Pemberi Rizki saat berada dalam keadaan kritis kehabisan uang. Saat hutang pada teman-teman menumpuk dan belum terbayarkan. Saat honor terjemahan terlambat datang, tempat aku menata hati, merancang strategi, memepertebal azam dan keteguhan jiwa dalam perjuangan panjang (Shirazy, 2005: 30).

Kutipan tersebut menggambarkan bahwa Fahri adalah seorang pemuda yang rajin salat berjamaah ke masjid. Ia tidak terhalang karena teriknya matahari atau jauhnya tempat tinggal, dan kesibukan apa pun yang dialaminya, ia tetap tidak melupakan salat. Salat merupakan kewajiban bagi semua orang Islam yang tidak boleh ditinggalkan dalam keadaan apa pun dan di man pun, karena sabar dan salat dapat mencegah kemungkaran.

Dalam novel Bumi Cinta juga digambarkan tokoh Ayyas sebagai seorang pemuda santri salaf yang rajin salat. Di tengah- tengah kesibukannya dan di man pun, ia selalu tidak meninggalkan salat dan membaca Alquran. Gambaran tersebut tampak pada kutipan berikut: “Yalena sampai di apartemen ketika Ayyas sedang salat. Suara Ayyas membaca Alquran ketika salat terdengar sangat jelas... yalena mendengar salam Ayyas, tanda salatnya telah selesai...." (Shirazy, 2010: 49).

Kerajinan salat Ayyas di mana pun digambarkan pada saat Ayyas di ruang Profesor Tomskii. Ia telah merebahkan tubuhnya di sofa sejenak. Ia telah memasang alarm sebagai tanda manjingnya waktu salat. Ia telah tertidur pulas, pada saat ponselnya berdering sebagai tanda telah manjing waktu salat. Ia segera bangun mengambil air wudhu dan melaksanakan salat. Gambaran tersebut tampak pada kutipan sebagai berikut: “ Ayyas meletakkan rangselnya di dekat sofa lalu merebahkan badannya... Ayyas terbangun ketika ponselnya meleking-leking. Berarti ia terlelap cukup lama... Lalu berwudhu dan menegakkan salat. Ayyas rukuk dan sujud di ruangan itu dengan penuh rasa khusuk dan menyatu dengan keagungan rahmat Allah Subhanahu wa Ta'ala"(Shirazy, 2010: 152).

Dalam novel Bumi Cinta juga digambarkan Ayyas meluruskan pandangan orang Barat yang memandang bahwa Islam selalu disebarkan dengan kekerasan dan pedang. Ayyas menjelaskan bahwa ketika Umar bin Khatab membuka Yerusalem, kedamaianlah yang dirasakan oleh masyarakat Yerusalem. Umar bin 
Khatab datang ke Yerusalem penuh dengan cita kasih dan hormat kepada pendeta dan penduduk Yerusalem. Tidak ada perusakan gereja, tidak ada pembunuhan, dan tidak ada kota dan desa yang dirusak. Gambaran tersebut tampak pada kutipan berikut: "Saat Islam membuka Yerusalem kedamaianlah yang dirasakan penduduk Yerusalem. Umar bin Khatab datang dengan penuh cinta dan hormat pada para pendeta di sana. Tak ada gereja yang dirusak. Tak ada desa dan kota yang dirusak...." (Shirazy, 2010: 73).

Ayyas tidak hanya rajin salat, tetapi ia juga sering puasa, karena puasa dapat membentengi diri dari perbuatan dosa, godaan syahwat dan godaan setan . Apalagi ia hidup di negeri yang sangat bebas pergaulan dan free sex. Setiap hari ia juga berhadapan dengan seorang perempuan yang sangat cantik dan menawan, kalau dirinya tidak dilindungi dengan iman yang kuat, imannya bisa roboh dan akan melakukan dosa besar. Ia selalu belajar menjaga imannya dan kesuciannya. Ia tidak akan melalukan hubungan dengan lawan jenis, kecuali dengan istrinya yang dilandasi kesucian dengan pernikahan. Gambaran tersebut tampak pada kutipan sebagai berikut:

"Maaf Doktor ... saya sedang puasa. Saya hampir lupa kalau saya sedang puasa. setan."

'Puasa untuk menjaga kesucian diri... Dari godaan syahwat dan godaan "Jadi puasa itu jadi semacam benteng di dalam jiwa dari godaan syahwat dan perbuatan jahat begitu?"

"Kira-kira begitu. Apalagi saya masih muda . Pemuda normal yang belum menikah. Dan sekarang sering bertemu dengan perempuan muda Rusia... Kalau saya tidak membentengi diri dengan benteng yang kuat, iman saya bisa roboh, saya bisa melakukan dosa besar yang dilarang agama saya."... Saya ingin menjaga kesucian diri saya dari perbuatan dosa itu.. kalau pun melakukan hubungan dengan lawan jenis,, saya ingin yang berlandaskan kesucian, yaitu menikah. Dengan menikah saya ingin memuliakan istri saya, saya ingin setia padanya sampai akhir hayat (Shirazy, 2010: 232).

Kutipan tersebu menggambarkan bahwa Ayyas seorang pemuda yang sangat taat menjalankan ajaran Islam. Ia rajin puasa untuk membentengi dirinya dari nafsu syahwat dan godaan setan. Ia kometemen selalu akan menjaga kesuciannya. Ia bercita-cita hanya ingin berhubungan dengan istrinya sebagai bentuk memuliakan istrinya dan mencintai istrinya sampai akhir hayatnya. 
Ajaran Islam yang terkait dengan puasa juga digambarkan dalam novel Bumi Cinta. Pada saat Ayyas berjalan dengan Pak Joko, ayas melihat pergaulan sepasang muda-mudi yang berciuman di pinggir jalan. Pak Joko menasiati Ayyas, jangan kaget, seperti itulah cara hidup sebagian besar anak muda di sini. Mereka hidup bebas. Semuanya hidup bebas, kecuali yang muslis dan sedikit ortodoks yang menjaga kesucian hidupnya. Kalu tidak kuat, berpuasalah dengan berpuasa jiwamu akan lebih tenang, dan nafsumu akan lebih jinak dan terkendali (Shirazy, 2010: 143).

\section{Konstruksi ajaran Islam yang berhubungan dengan akhlak}

Dalam perndahuluan telah dijelaskan bahwa akhlak merupakan pondasi utama dalam pembentukan karakter pribadi manusia, untuk merealisasikan akhlak dalam kehidupan, perlu adanya pembinaan secara terus menerus (Sylviyanah, 2012:191). Akhlak merupakan warisan maknawi Rasulullah yang amat bernilai karena Rasulullah diutus ke dunia untuk menyempurnakan akhlak manusia.

Kata akhlak berasal dari bahasa Arab alakhlaq yang merupakan bentuk jamak dari kata khuluq yang berarti budi pekerti, perangai, tingkah laku, atau tabiat. Kata akhlak dapat disamakan dengan etika dan moral. Akhlak dapat berarti keadaan gerak jiwa yang mendorong ke arah melakukan perbuatan dengan tidak menghajatkan pikiran ( Marzuki,2012:8).

Secara objektivasi, masyarakat akan mengahsilkan realitas sosial atau fenomena sosial yang ada dalam masyarakat. Masyarakat yang baik akan menghasilkan realitas sosial yang cenderung baik, yaitu masyarakat yang religius. Dalam novel Ayat-Ayat Cinta digambarkan tokoh Fahri merupakan salah tokoh utama yang memiliki akhlak yang baik, suka menolong orang lain, menghormati orang lain, sehingga banyak desenagi orang. Bukan hanya guru ngajinya para Syaikh yang menyayangi Fahri, tetapi juga banyak perempuan cantik yang mencintai Fahri, seperti Maria, Nurul, Noura, dan Aisha.

Akhlak baik Fahri tersebut tampak bahwa Fahri sering menolong oran lain yang tanpa mengharapkan balasan apa-apa. Bila ia menolong orang lain, hanya karena cintanya kepada Allah SWT. Ia pernah menolong Maria memberikan disket di tengah-tengah kesibukannya, tetapi ia juga tidak mau uangnya yang telah digunakan untuk membeli disket dikembalikan. 
Fahri juga pernah menolong perempuan bercadar putih yang sedang berbuat baik kepada orang Amirika dengan memberikan tempat duduknya, tetapi perempuan tersebut justru dimarahi dan dicaci maki oleh orang Mesir. Fahri membela perempuan tersebut, sudah berbuat baik justru dimarahi dan dicaci maki, karena ia dianggap tidak toleran kepada orang Mesir, karena orang Amirika telah banyak membuat kadhaliman dan kesengsaraan bagi masyarakat Arab pada umumnya. Perempuan bercadar tersebut akhirnya mengucapkan terima kasih kepda Fahri. Fahri mengatakan beterima kasihlah kepada Tuhan, karena ia menolong hanya karena kecintaannya kepada Tuhannya.

Akhlak baik Fahri juga tampak pada saat ia menolong perempuan cantik yang bernama Noura, yang sedang menghadapi kesulitan karena perbuatan ayahnya. Ia berusaha menyelamatkan dari siksaan ayahnya, meskipun ia akhirnya justru difitnah oleh ayahnya bahwa ia telah memperkosa Noura, sehingga ia harus di tahan dan menghadapi proses hukum di pengadilan.

Sebagai seorang muslim, Fahri juga berbuat baik kepada tetangganya, yaitu keluarga Maria, sehingga keluarga Maria juga sangat senang kepada Fahri. Bahkan Maria sendiri sebenarnya juga jatuh cinta kepada Fahri. Fahri selalu berpegang teguh kepada ajaran Islam bahwa orang Islam harus menghorti tetangganya, tidak boleh menyakiti tetangganya.

Fahri juga sangat menghormati wanita dan mau menyakiti atau menyinggung perasaan wanita. Pada saat ia diajak berkenalan dengan perempuan bercadar dengan mengulurkan tangannya untuk berjabat tangan dengan Fahri, dengan rasa hormat, Fahri minta maaf sambil menangkupkan kedua tangannya ke dadanya, sebagai tanda rasa hormat kepada perempuan tersebut.

Pada saat ia diajak bermain dansa oleh Maria ketiak Fahri diajak makan di lestoran oleh kedua orang tua Maria, Fahri juga minta maaf tidak bisa melakukan permintaan Maria, karena ia berpegang teguh pada ajaran Islam bahwa seorang laki-laki tidak boleh bersentuhan dengan perempuan yang bukan muhrimnya.Berbagai contohperistiwa yang dialami Fahri tersebut menunjukkan kebaikkan akhlak Fahri.

Dalam novel Ayat-Ayat Cinta diagambarkan tokoh Fahri dan Aisha merupakan manusia yang memiliki akhlak yang baik. Keduanya merupakan 
suami-istri yang saling mencintai, menghargai, menghormati, dan tidak saling menyakiti. Fahri sebagai suami sangat mencintai, menghormati, dan menghargai istrinya. Sebaliknya Aisha sebagai istri juga saling mencintai, menghargai, menghormati, dan tidak saling menyakiti. Fahri digambarkan sebagai seorang mahasiswa yang rajin, pandai, dan berakhlak mulia, suka menolong, menghormati, dan tidak mau menyakiti orang lain. Akhlak, kepandaian, keramahan Fahrilah yang menyebabkan ia banyak disukai orang lain. Ia juga banyak dicintai wanita cantik, seperti Maria.

Kebaikan akhlak Fahri juga tampak pada saat ia ditahanan, ia tidak mau makan makanan yang dibawakan istrinya, karena ia tidak mau makan enak, sementara teman-teman seselny hanya makan air dan roti kering. Perasaan toleransi Fahri sangat tinggi kepada sesama tahanan. Ia tidak mau makan enak, sementara temannya hanya minum seteguk air dan roti kering. Aisha segera tanggap, maka dibaginya makanan tersebut dua bagian, sebagian untuk suaminya, dan sebagian utuk temannya. Hal tersebut tampak pada kutipam sebagai berikut: “Untuk buka puasanya mungkin aku tidak bisa, jawabku”. "Kenapa?" "Aku tidak mungkin makan sementara teman-teman satu selku berbuka hanya dengan seteguk air dengan roti kering dengan jubna kadaluarsah"(Sharazy, 2005: 354).

Dalam novel Bumi Cinta juga digambarkan akhlak Mok Jum yang baik, suka ngalah, sabar, dan suka bersedekah kepada orang lain secara iklas. Ketika Mbok Jum melayani pelanggannya Pak Turah membeli nasi sambal tumbang satu bungkus memberi uang lima ribu rupiah, harganya empat ribu rupiah, maka uangnya dikembalikan seribu rupiah. Tetapi, Pak Turah marah-marah minta pengembaliannya kurang lima ribu. Karena uang yang diberikan tadi sepuluh ribu, padahal hanya lima ribu. Mbok Jum ngalah biarlah di lebih rela nambah lima ribu kepada Pak Turah lima ribu daripad ramai. Ia sebenarnya tahu yang benar dia, tetapi Mbok Jum ngalah, sambil bersedekah dan minta barohak rezeki kepada Allah dan mohon doa kepada Allah agar Pak Turah menjadi insaf dan baik. Ia berharap agar seluruh saudaranya, tetangganya, kenalannya, semuanya baikk dan mendapat rahmat dari Alaah SWT. Mnok Jum juga sadar bahwa orang hidup itu sebenarnya untuk beribadah. Akhlak Mbok Jum tersebut tampak dalam kutipan berikut: 
Karena aku merasa benar itulah maka aku mengalah. Ya nggak apa-apa sedekah beberapa ribu rupiah. Dengan sedekah itu aku minta barokahnya rezeki, dan aku minta kepda Allah semoga Pk Turah jadi insaf dan baik. Semuanya jadi baik. Aku ingin seluruh saudaraku, tetangga-tetanggaku, kenalanku, semuanyabaik dan dirahmati Gusti Allah. Intinya kita hidup kan untuk ibadah tho Le.... (Shirazy, 2010: 76).

Dalam novel tersebut juga digambarkan akhlak baik Ayyas. Ia suka menolong orang lain, termasuk menolong Yalena pada saat ia disiksa dan akan dibunuh oleh tiga laki-laki hidung belang lengganannnya. Pada saat Yalena akan membalas kebaikan Ayyas yang telah menolongnya, Ayyas justru mengatakan bahwa ia tidak merasa berbuat apa-apa kepada Yalena selain hanya melakukan kewajiban yang diperintahkan Allah kepadanya. Dalam Islam diajarkan bahwa menolong atau menyelamatkan nyawa satu anak manusia sama saja dengan menyelamatkan nyawa seluruh umat manusia. Hal tersebut tampak dalam kutipan sebagai berikut: "Berilah aku kesempatan kebaikanmu”."Aku sudah bilang bahwa aku merasa tidak berbuat apa-apa kepadamu, selain aku hanya melakukan sebuah kewajiban yang diperintahkan oleh Tuhan kepadaku.” ...Dalam Islam diajarkan bahwa menyelamtkan satu nyawa anak manusia itu sama dengan menyelamtkan nyawa seluruh umat manusia" (Shirazy, 2010 227).

Akhlak baik Ayyas juga digambarkan dalam novel Bumi Cinta. Pada saat Sofi alias Linor ditembak orang di jalan, ia segera menolongnya. Ia membopong tubuh Sofia sambil mencari mobil yang bisa mengantarkan Sofia ke rumah sakit. Ia selalu berdoa agar Sofia masih bisa hidup. Ia berjanji dalam hatinya bila Sofia hidup, ia kan mengawininya, akan dijadikan teman seperjuangan dijalan Allah. Ia akan dijadikannya sebaga satu-satunya bidadari surga baginya. Gambara tersebut tampak dalamkutipan berikut: "Ayyas meraih tubuh Sofia dan meletakkan di pangkuannya. Ia meraba nadinya. Masih berdeyut ... Ayyas membopong Sofia dan membawanya berjalan ke arah jalan yang lebih besar... Dalam hati Ayyas berdoa agar Allah menyelamtkan nyawa Sofia. Ia berjanji kepada Allah, jika Sofia selamat, ia akan menikahinya dan menjadikannya sebagai teman berjuang di jalan-Nya sampai maut datang menjemputnya. Ia juga berjanji, jika Sofia selamat, ia akan menjadikannya sebagai satu-satunya bidadari surga baginya (Shirazy, 2010: 542). 
Kutipan tersebut mengandung makna bahwa menolong kepada sesama itu tidak harus mendapat balasan dari yang ditolong. Menolong orang lain, apalagi menyelamatkan nyawa manusia merupakan sebuah kewajiban bagi orang Islam, karena menolong nyawa satu orang, sama saja dengan menyelamatkan nyawa seluruh umat manusia dan mendapat pahala yang besar dari Allah SWT.

\section{Konstruksi Ajaran Islam yang Berhubungan dengan Muamalah}

Dalam pendahuluan telah dijelaskan bahwa muamalah adalah kegiatan manusia yang terkait dengan duniawi, baik yang terkait dengan kepentingan diri sendiri maupun yang terkait dengan kepentingan masyarakat yang memberikan manfaat dengan cara yang telah ditentukan, seperti jual beli, tukar menukar barang, sewa-menyewa, upah-mengupah, pinjam-meninjam, bercocok tanam, berserikat, tolong-menolong, dan usaha lain (Rasjid, 2010:278).

Dalam novel Novel Ayat-Ayat Cinta digambarkan bahwa Fahri adalah seorang yang mempunyai kepedulian dan senang membantu orang lain serta berbuat baik dan menghormati tetangga. Ia dengan ikhlas membantu Maria tetangganya membelikan disket dan tidak menharapkan apa-apa, bahkan setelah barangnya diberikan kepada Maria. Ia tidak menharapkan uangnya dikembalikan. Ia menolong orang lain sebagai refleksi cintanya kepada Allah SWT, hanya mengharapkan ridho dari Allah SWT. Hal tersebut tampak dalam kutipan sebagai berikut: " di kota Helwan ada pasar dan toko-toko cukup besar. Di sana, akhirnya kudapatkan juga disket itu. Aku beli empat. Dua untuk Maria. Dan dua untuk diriku sendiri" (Shirazy, 2005: 58).

Fahri sebagai pemuda muslim selalu berusaha mengamalkan ajaran Islam dalam hidup di masyarakat, termasuk suka menolong, berbuat baik, dan memuliakan tetangganya. Islam juga mengajarkan bahwa setiap manusia itu pada dasarnya adalah saudara. Oleh sebab itu, manusia harus saling cinta- mencintai, tolong menolong, dan berbuat baik kepada sesama dan tetangga. Ia juga sangat mencintai dan saling tolong menolong di antara sesama teman seasrama, masingmasing mengetahui tanggung jawabnya. Saling mencintai dan tolong menolong merupakan bentuk persaudaraan dan rasa cinta sesama saudara. Hal tersebut tampak pada kutipan sebagai berikut: "Aku senang bahwa teman-teman satu rumah ini mengerti dengan kewajiban masing-masing. Kewajiban memasak 
sesibuk apa pun adalah hal yang tidak boleh ditinggalkan. Sepertinya remeh tapi sangat penting untuk sebuat tanggung jawab. Masak tepat waktunya adalah bukti paling mudah sebuah rasa cinta sesama saudara. Ya inilah bentuk persaudaraan. Hidup di negeri orang harus saling membantu dan melengkapi. Tanpa orang lain mana mungkin kita bisa hidup dengan baik" (Shirazy, 2005: 65).

Mendahulukan kepentingan orang lain juga merupakan bentuk ajaran Islam. Fahri sebagai seorang muslim yang telah dididik di pesantren dan di perguruan tinggi Islam Al-Ashar, ia tahu bahwa Islam mengajarkan agar lebih mementingkan orang lain daripada kepentingan dirinya sendiri. Ajaran Islam di pesantren dan di perguruan tinggi Islam itulah yang menyebabkan Fahri mampu menerapkan ajaran Islam dalam kehidupan di dalam masyarakat. Masyarakat pada dasarnya memproduk manusia, maka bila seseorang hidup dalam masyarakat yang baik, maka dalam hidup dalam masyarakat ia akan selalu cenderung untuk berbuat kebaikan. Manusia sebagai individu juga memproduk masyarakat, artinya bila manusia itu baik, maka masyarakatnya juga akan baik.

Dalam novel Novel Ayat-Ayat Cinta juga mengajarkan kepada suami-istri agar saling mencintai, menghormati, dan tidak saling menyakiti. Seorang suami harus mencintai, menghormati, dan tidak menyakiti istrinya. Sebaliknya, seorang istri juga harus mencintai, menghormati, dan tidak menyakiti suaminya. Hubungan suami-istri harus satu jiwa, bila suami sakit, istri juga ikut sakit. Bila istri sakit, suami juga ikut sakit. Bila suami senang, istri juga senang, bila suami sedih, istri juga ikut sedih. Bila istri sedih, suami juga ikut sedih. Milik suami, juga milik istri, milik istri juga milik suami. Kecintaan suami kepada istrinya digambarkan dalam kecintaan Fahri kepada Aisha. Fahri sangat mencintai dan menghormati istrnya. Kecintaan Fahri kepada istrinya tampak pada dialog sebagai berikut: "Aku sangat mencintainya, tapi aku tidak akan mampu menuruti keinginannya ....” Aisha, istriku yang kucintai.... (Shirazy, 2005: 268 dan 270).

Kecintaan Aisha kepada suaminya, penghormatan istri kepada suaminya, tutur bahasa yang halus dan sopan istri kepada suaminya juga digambarkan dalam diri Aisha Aisha merupakan istri Fahri yang sangat setia dan menghormati suaminya. Ia tidak mau membuat suaminya sedih, karena kesedian suaminya juga 
kesediannya, kegembiraan. Hal tersebut tampak dalam dialog Aisha dengan suaminya sebagai berikut:

Suamiku, kita ini satu jiwa.Kau adalah aku. Dan aku adalah kau. Kita akan mengarungi kehidupan ini bersama. Dukamu dukaku. Dukaku dukamu. Sukamu sukaku. Sukaku sukamu. Cita- citaku cita-citamu.Senangmu senangku. Senangku senangmu. Bencimu benciku. Benciku bencimu. Kuramu kurangku. Kurngku kurangmu. Kelebianmu kelebianku. Kelebianku kelebianmu. Milikmu milikku. Miliku milikmu. Hidupmu hidupku. Hidupku hidupmu” .... (Shirazy, 2005: 271).

Seorang istri juga tidak boleh membuat suaminya merasa sedih, meminta sesuatu yang sekiranya suaminya tidak bisa menurutinya. Seorang istri yang meminta sesuatu kepada suaminya dan suaminya tidak dapat menuruti permintaan istrinya, berarti sudah membuat suaminya sedih. "Suamiku, alangkah celakanya aku kalau sampai aku membuatmu sedih. Kalau sampai aku meminta sesuatu yang diluar kemampuanmu. Alangkah celaknya diriku ....” (Shirazy, 2005: 268 dan 270). Aisha merupakan contoh istri yang baik, yang tidak mau membuat suaminya sedih. Ia tidak mau meminta sesuatu yang sekiranya suaminya tidak bisa menuruti permintaannya. Ia bahkan merasa celaka bila meminta sesuatu di luar kemampuan suaminya, yang akan membuat suaminya merasa sedih.

Perilaku dan karakter Aisha merupakan produk keluarga dan masyarakat. Ia dididik dalam keluarga yang kaya, harmonis, saling mencitai, dan hidup di negara Mesir yang terkenal sangat baik budinya dan halus tutur bahasanya, sehingga menghasilkan Aisha yang selalu berperilaku yang baik, tutur bahasanya yang lemah lembut, sangat menghormati suaminya, sehingga perilaku dan karakter sehari-harinya juga selalu baik. Aisha sebagai individu juga ikut berperan membentuk masyarakat yang baik dan bertutur bahasa yang halus dan sopan. Pada dasarnya orang Mesir asli adalah bangsa yang suka memuliakan tamu, sangat ramah, pemurah hatinya lembut penuh kasih sayang. Sifat mereka sangat lembut, suka memuliakan tamu, dan sangat memanusiakan manusia seperti sifat Nabi Yusuf, dan Nabi Ya'kub, Syaikh Sya'rawi, Syaikh Muhammad.... (Shirazy, 2005: 47).

Dalam novel Ayat-Ayat Cinta juga mengajarkan kepada istri bahwa seorang istri harus mempercayakan semua urusan ekonomi kepada suaminya, suamilah yang mengaturnya, karena suaminya adalah kepala keluarga dan 
sekaligus imam bagi istri dan anak-anaknya. Istri juga harus mempercayai suaminya untuk mengatur urusan keluarga. Aisha sebagai istri sangat mencintai dan mempercayai suaminya agar mengatur seluruh urusan keluarga, karena suaminya adalah imamnya. Semua miliknya juga milik suaminya. Ia serahkan tabungan hasil warisan dari ibunya untuk mengelolanya. Hal tersebut tampak pada kutipan berikut: “ Terima kasih suamiku, kau tidak menganggap diriku sebagai orang lain. Aku akan menjelaskan semua hal yang terkait dengan ATM itu dan apa yang aku miliki saat ini. Aku ingin kau yang mengaturnya sepenuhnya. Sebab kau adalah imamku dan aku sangat percaya padamu” .... (Shirazy, 2005: 272).

Dalam novel Ayat-Ayat Cinta juga mengajarkan kepada orang tua, agar bila membagi harta benda warisan kepada anak- anaknya bisa berbuat adil dan tetap saling menjaga hubungan persaudaraan dan rasa solidaritas di antara anakanaknya. Anak-anaknya tetap bisa hidup layak. Jangan sampai justru harta benda warisan mengakibatkan putusnya bungan persaudaraan.

Dalam novel Bumi Cinta juga mengajarkan bahwa Islam mengajurkan agar manusi bekerja demi membangun kejayaan duniawi sebagai bekal di akhirat kelah, karena sesungguhnya surga itu adalah hasil menanamkan kebaikan ketika di dunia. Rasulullah juga bersamda bahwa dinia adalah ladang akhirat, artinya apa yang dipetik di akhirat merupakan hasil amal kebaikan atau ibadah yang telah ditanam di dunia. Tanpa seseorang menanamkan amal kebaikan atau ibadah ketika di dunia, tidak mungkin akan memetik kebahagiaan di akhirat. Islam mengajarkan keseimbangan antara kepentingan di dunia dan di akhirat. Tidak boleh ada ketidakseimbangan antara kepentingan dunia dengan kepentingan di akhirat.

Rasulullah bersabda bahwa manusia harus bekerja seolah-olah akan hidup seribu tahun lagi dan beribadah seolah-olah akan mati besuk. Maknanya manusia harus rajin bekerja dan beribadah ketika di dunia bagaikan menannm yang kan dipetik hasilny di akhirat kelak. Rasulullah juga bersabda bahwa seseorang yang bekerja untuk anak-anaknya, maka pahanya sama dengan berjuang di jalan Allah. Harta yang dibelanjakan ke jalan Allah, harta yang digunakan untuk memerdekakan budak, harta yang diberikan kepada fakir miskin, dan harta yang dibelanjakan untuk keluarga, maka diantara ketiga amalan tersebut, harta yang 
dibelanjakan untuk keluarga adalah yang paling besar keutamaannya (Shirazy, 2010: 387-388).

\section{SIMPULAN}

Berdasarkan uraian dalam pembahasan dapat disimpulkan bahwa secara eksternalisasi, masyarakat merupakan produk manusia. Masyarakat pesantren, sekolah keagamaan sepeti Madrasah Aliyah, Universitas di Madinah, Universitas Cairo, masyarakat Madinah, dan masyarakat Mesir yang pada umumnya baik merupakan produk manusia yang baik seperti tokoh Fahri, Ayyas, santri, ustad, dan kiayi

Secara objektivasi, masyarakat yang baik seperti masyarakat pesantren, sekolah keagamaan sepeti Madrasah Aliyah, Universitas di Madinah, Universitas Cairo, masyarakat Madinah, dan masyarakat Mesir yang pada umumnya baik akan mengahsilkan realtas sosial atau fenomena sosial yang baik yang anggota masyarakatnya akan cenderung melakukan hal-hal yang mengarah kepada kebaikan.

Secara internalisasi, manusia merupakan produk masyarakat. Fahri sebagai manusia yang memiliki iman yang kuat, pandai, hafal Alquran, dan mempunyai akhlak yang baik merupakan produk masyarakat, yaitu produk keluarga Fahri yang sederhana, Madrasah Aliyah tempat belajar, Universitas AlAsyhar, dan budaya kehidupan Masyarakat Mesirlah yang religius. Demikian juga, orang-orang atau manusia Mesir yang memiliki budaya membaca Alquran di metro, di bis, di stasiun, di terminal juga merupakan produk masyarakat Mesir yang religius.

Kekuatan iman Ayyas yang selalu berjuang dan mempertahankan imannya di tengah-tengah kehidupan masyarakat yang menganut bahkan menuhankan kebebasan pergaulan dan free sex. Untuk mempertahankan imannya, ia selalu salat, membaca Alquran, zikir, dan bertasbih serta selalu menjaga pandangannya dari perempuan cantik. Ayyas sebagai pemuda santri salaf yang sangat kuat imannya tersebut merupakan produk dari masyarakat pesantren dan masyarakat Madinah yang baik dan religius. Demikian juga, Yalena dan Linor yang sangat 
bebas dalam pergaulan dan free sex juga merupakan produk masyarakat Rusia yang menuhankan kebebasan pergaulan dan free sex.

\section{DAFTAR PUSTAKA}

Bailey, Kenneth D. 1987. Methods of Social Research. New York: The Free Press.

Berger, Peter L. \& Thomas Luckmann 1990. Tafsir Sosial atas Kenyataan: Risalah tentang Sosiologi Pengetahuan (diterjemahkan dari buku asli The Social Construction of Reality oleh Hasan Basari). Jakarta: LP3ES

Daud, Ma'mur. 2003. Terjemahan Hadist Shahih Muslim. Jakarta: Penerbit Wijaya.

Hanafi, Syafiq Mamadah dan Ahmad Sobirin. 2002. "Relevansi Ajaran Agama Dalam Aktivitas Ekonomi ( Studi Komparatif antara Ajaran Islamdan Kapitalisme)". Igtisad, Journal of Islamic Economics. Volume 3, Nomer 1, Muharam 1423 H/ Maret 2002.

Manuaba, I.B. Putra. 2010. “Teori Konstruksi Sosial”. Jurnal Masyarakat Kebudayaan dan Politik. Volume 21, Nomer 3:221-230.

Marzuki. 2009. Prinsip Dasar Akhlak Mulia, Pengantar Studi Konsep-Konsep Dasar Etika dalam Islam. Yogyakarta : Debut Wahana Press. (www.staf.uny.ac.id).

Moleong, Lexy J. 2004. Metodologi Penelitian Kualitataif. Bandung: Remaja Rosdakarya.

Nasuha, A. Chozin. 2009. "Konsep Islam dalam Pemikiran ISIF".Jurnal IslamIndonesia: Volume 01, Nomor 01, Tahun 2009/1431

Rasjid, 2010. Fiqih Islam. Bandung: sinar Baru.

Shirazy, Habiburahman El. 2004.Ayat-ayat Cinta.Jakarta : Ihwah Publising Hause.

------ 2011. Bumi Cinta. Jakarta : Ihwah Publising Hause.

Supratno, Haris. 2010. Sosiologi Seni, Wayang Sasak Lakon Dewi Rengganis dalam Konteks Perubahan Masyarakat di Lombok. Surabaya: University Press.

2010. “Aktualisasi Nilai-nilai Tradisi Lisan Berwawasan Kepulauan Sebagai Model Pendidikan Karakter Bangsa" . Makalah disajikan dalam Seminar Nasional di Universitas Patimura Ambon, tanggal 25 Nopember 2010 di Ambon. 